\title{
PENILAIAN TINGKAT PEMBERIAN KREDIT TERHADAP KESEHATAN BANK PADA BANK PEMBANGUNAN DAERAH KALIMANTAN TIMUR \\ Oleh :
}

\author{
Muhammad Astri Yulidar Abbas* \\ Erni Setiawati* \\ ( *Dosen Fakultas Ekonomi Universitas Widya Gama Mahakam Samarinda )
}

\begin{abstract}
ABSTRAK
Tujuan penelitian ini adalah untuk menganalisa dan mengevaluasi tingkat Kesehatan Bank Pembangunan Daerah Kalimantan Timur berdasarkan Rasio penilaian rasio Non Performance Loan (NPL) dan Loan to Deposit Ratio (LDR) periode 2009-2013.

Metode penelitian ini menggunakan metode deskriptif kuantitatif yaitu penelitian penjelasan (Explanatory Research) yang dilakukan untuk memperoleh gambaran yang sebenarnya tentang tingkat kesehatan pada Bank Pembangunan Daerah Kalimantan Timur serta menggunakan alat analisis Rasio Non Performance Loan (NPL) dan Loan to Deposit Ratio (LDR).

Dari hasil analisis BPD Kaltim pada periode 2009-2013 memiliki NPL yang fluktuatif, secara umum rasio NPL rata-rata adalah 2,05\%, sedangkan perhitungan menggunakan rasio LDR BPD Kaltim pada tahun 2009-2013 memilki rasio yang fluktuatif setiap tahunnya dengan rata-rata $70,63 \%$. Dari kedua rasio yang digunakan secara umum BPD Kaltim masuk kategori bank sehat.
\end{abstract}

Kata kunci : BPD, kredit, NPL, LDR

\section{PENDAHULUAN}

\section{Latar Belakang Masalah}

Bank Pembangunan Daerah Kalimantan Timur (disingkat BPD Kaltim) atau dikenal dengan Bankaltim adalah bank yang sahamnya dimiliki oleh pemerintah provinsi Kalimantan Timur sebesar lebih dari $51 \%$ dan sisanya oleh pemerintah Kabupaten/Kota yang ada di wilayah administrasinya (saat ini masih termasuk didalamnya pemerintah Provinsi Kalimantan Utara dan Kabupaten/Kota). Berdiri pada 14 Oktober 1965, dengan payung hukum Perda no. 03/PD/64 tanggal 19 September 1964 yang kemudian disetujui oleh Menteri Dalam Negeri melalui SK no. 9/10/8-45 tanggal 1 April 1965.

Keberadaan BPD Kaltim didirikan adalah dengan maksud dan tujuan untuk membantu dan mendorong pertumbuhan perekonomian \& pembangunan daerah di segala bidang serta sebagai salah satu sumber pendapatan asli daerah dalam rangka meningkatkan taraf hidup rakyat sehingga terwujudnya masyarakat Kalimantan Timur yang sejahtera. Dengan kehadiran BPD Kaltim, masyarakat yang selama ini belum mendapatkan Pelayanan Perbankan, khususnya pengusaha - pengusaha kecil di pedesaan, sudah dapat dilayani. 
Dari jumlah anggota masyarakat penabung dan peminjam yang telah berhasil dilayani, maka kehadiran BPD Kaltim dalam perekonomian nasional cukup memberikan arti terutama bagi masyarakat menengah kebawah yang sebagian besar berada di wilayah Pedesaan.

Kegiatan BPD Kaltim lebih banyak diarahkan kepada masyarakat pedesaaan dan golongan ekonomi lemah menuntut adanya pola pendekatan secara lebih persuasif dengan melihat karakter dari masing-masing nasabah yang beraneka ragam secara lebih cermat. Semakin besar jumlah kredit yang disalurkan oleh suatu bank, semakin besar pula modal yang harus disediakan oleh pemegang saham.

Pihak bank selalu dihadapkan pada resiko yang cukup besar apakah dana dan bunga dari kredit yang diberikan akan dapat diterima kembali sesuai dengan yang telah dijanjikan dalam ikatan perjanjian kredit. Jadi proses pemberian kredit tidak berakhir setelah kredit tersebut direalisasi, tetapi masih diperlukan pengawasan terhadap kegiatan debitur agar seluruh kredit beserta bunga dapat dibayar sesuai dengan prosedur yang disepakati.

Berdasarkan uraian diatas, penulis tertarik untuk mengetahui pengaruh tingkat pemberian kredit terhadap kinerja keuangan atau kesehatan bank pada Bank Pembangunan Daerah Kalimantan Timur melalui suatu penelitian dengan judul "Penilaian Tingkat Pemberian Kredit terhadap Kesehatan Bank pada Bank Pembangunan Daerah Kalimantan Timur".

\section{Perumusan Masalah}

Berdasarkan latar belakang penelitian yang telah dikemukakan diatas, maka penulis mencoba menyimpulkan rumusan masalah yang dapat mengarahkan penyelesaian penelitian ini, yaitu Bagaimana tingkat kesehatan Bank Pembangunan Daerah Kalimantan Timur berdasarkan penilaian rasio Non Performance Loan (NPL) dan Loan to Deposit Ratio (LDR)?

\section{Tujuan Penelitian}

Adapun yang menjadi tujuan dari penelitian ini adalah untuk menganalisis dan mengevaluasi tingkat kesehatan Bank Pembangunan Daerah Kalimantan Timur berdasarkan Rasio penilaian rasio Non Performance Loan (NPL) dan Loan to Deposit Ratio (LDR) periode 2009- 2013.

\section{TINJAUAN PUSTAKA}

\section{Penelitian Terdahulu}

Ayu Putri Intan Pertiwi (2010); Yang bersangkutan meneliti tentang kondisi bank yang terdaftar di Bursa Efek Indonesia periode 2004 - 2007 dengan judul "Rasio CAMEL sebagai Indikator Tingkat Kesehatan dan Kebangrutan Perbankan". Pada penelitian tersebut dapat disimpulkan bahwa Non Performance Loan (NPL) dan Return of Equity (ROE) signifikan berpengaruh terhadap kinerja keuangan bank.

Yunita Saragih (2011); Penelitian berjudul "Analisis Pengaruh Non Performance Loan (NPL) dan Loan to Deposits Ratio (LDR) terhadap Profitabilitas PT. Bank Tabungan Negara (Persero)" menyimpulkan bahwa 
secara bersama - sama (simultan) Non Performance Loan (NPL) dan Loan to Deposits Ratio (LDR) berpengaruh signifikan terhadap Profiltabilitas PT. Bank Tabungan Negara (Persero), Tbk.

\section{Dasar Teori}

Menurut Ikatan Akuntan Indonesia, Bank adalah lembaga yang berperan sebagai perantara keuangan (financial intermediary) antara pihak yang memiliki dana dan pihak yang memerlukan dana, serta lembaga yang berfungsi memperlancar lalu lintas pembayaran ${ }^{1}$

\section{Kredit}

Undang-Undang No.7 Tahun 1997 tentang perbankan sebagaimana telah diubah dengan Undang-Undang No.10 Tahun 1998 memberikan pengertian mengenai kredit sebagai berikut "Kredit adalah penyediaan uang atau tagihan yang dipersamakan dengan itu, berdasarkan persetujuan atau kesempatan pinjam meminjam antara Bank dengan pihak lain yang mewajibkan pihak lain untuk melunasi utangnya setelah jangka waktu tertentu dengan jumlah bunga, imbalan atau pembagian hasil keuntungan'2

Berdasarkan pengertian diatas, maka ditarik beberapa kesimpulan, yaitu:

1. Adanya dua pihak yang saling berkepentingan, yaitu pihak penyedia uang (kreditur) dan pihak peminjam uang (debitur). Kedua pihak tersebut melaksanakan atas perjanjian pinjam meminjam, dimana keduanya harus mematuhi semua syarat dan kewajiban masing-masing

2. ${ }^{3}$ Terdapat suatu penyerahan uang, tagihan atau juga dapat berupa barang yang menimbulkan tagihan kepada pihak lain, dengan harapan Bank sebagai kreditur akan memperoleh suatu tambahan nilai dari pokok pinjaman tersebut yang berupa uang, imbalan atau pembagian hasil keuntungan

3. Terjadi suatu kesepakatan bersama tentang pelunasan utang, jangka waktu dan jaminan serta jumlah bunga, imbalan maupun pembagian hasil keuntungan yang akan diselesaikan dalam jangka waktu tertentu.

Terdapat dua unsur dalam pemberian kredit, yaitu unsur keamanan (safety) dan unsur keuntungan (profitability). Kedua unsur ini tidak dapat dipisahkan satu sama lain karena saling berkaitan erat.

1. Unsur keamanan (safety) maksudnya adalah, bahwa prestasi yang diberikan ke dalam bentuk uang, barang, atau jasa tersebut benar-benar terjamin pengembaliannya, sehingga keuntungan atau profitability yang diharapkan dapat tercapai.

2. Unsur keuntungan (profitability), merupakan tujuan dari membetikan kredit yang menjelma dalam bentuk bunga, imbalan ataupun pembagian hasil keuntungan. Tujuan pemberian kredit tidaklah semata-mata untuk mencari keuntungan, selain itu pemberian kredit juga ditujukan untuk meningkatkan taraf hidup rakyat dan pemerataan pembangunan.

\footnotetext{
${ }^{1}$ Ikatan Akuntansi Indonesia, 2009, Standar Akuntansi Keuangan, Salemba Empat, Jakarta, halaman 31

${ }^{2}$ Peraturan Bank Indonesia, http://www.bi.go.id, diakses 23 September 2014
} 
Menurut Kasmir, kata kredit berasal dari bahasa yunani yaitu "credere" yang artinya adalah "percaya" maksudnya adalah apabila seseorang memperoleh kredit, maka berarti ia memperoleh kepercayaan dan mempunyai kewajiban untuk membayar kembali pinjaman tersebut, dan si pemberi kredit percaya kepada si penerima kredit bahwa uang yang dipinjamkan pasti kembali sesuai dengan perjanjian ${ }^{4}$

Dari pengertian kredit diatas dapat diketahui unsur-unsur yang terkandung dalam pemberian fasilitas, yaitu :

a. Kepercayaan

Kepercayaan merupakan keyakinan sipemberi kredit bahwa kredit yang diberikan akan benar-benar diterima kembali diwaktu tertentu dimasa yang akan datang. Kepercayaan ini diberikan oleh pemberi kredit setelah melakukan penelitian dan penyelidikan yang mendalam tentang di penerima kredit. Penelitian dan Penyelidikan dilakukan untuk mengetahui kesungguhan dan kemampuannya dalam membayar kredit yang diberikan.

\section{b. Kesepakatan}

Kesepakatan antara si pemberi kredit dengan si penerima kredit dituangkan dalam suatu perjanjian dimana tiap-tiap pihak menandatangani hak dan kewajibannya masing-masing.

\section{c. Jangka waktu}

Kredit yang diberikan memiliki jangka waktu tertentu, jangka waktu ini mencakup masa pengembalian kredit yang telah disepakati.

\section{d. Resiko}

Faktor resiko kerugian dapat diakibatkan dua hal, yang pertama yaitu resiko kerugian yang diakibatkan musibah yang dialami oleh nasabah seperti bencana alam atau bangkrutnya usaha nasabah tanpa ada unsur kesengajaan. Resiko ini menjadi tanggungan bank, baik resiko yang disengaja maupun yang tidak disengaja.

e. Balas Jasa

Bagi bank, balas jasa merupakan keuntungan atau pendapatan atas pemberian suatu kredit. Balas jasa dapat berbentuk bunga, biaya provisi dan komisi serta biaya administrasi kredit.

\section{Tujuan dan Fungsi Kredit}

Pemberian suatu fasilitas kredit mempunyai tujuan dan fungsi tertentu. Tujuan pemberian kredit pada suatu Bank adalah :
a. Mencari keuntungan
b. Membantu usaha nasabah
c. Membantu pemerintah

\footnotetext{
${ }^{4}$ Kasmir, 202, Dasar-Dasar Perbankan, Edisi Pertama, Cetakan Pertama, Penerbit PT. Raja Grafindo Persada, Jakarta, halaman 59
} 
Adapun Fungsi Kredit secara umum, yaitu :

a. Untuk meningkatkan daya guna uang,

b. Untuk meningkatkan peredaran dan lalu lintas uang,

c. Untuk meningkatkan daya guna barang,

d. Untuk meningkatkan peredaran uang,

e. Sebagai stabilitas ekonomi,

f. Untuk meningkatkan kegairahan berusaha,

g. Untuk meningkatkan pemerataan pendapatan,

h. Untuk meningkatkan hubungan internasional.

\section{Tingkat Kualitas Kredit}

Tingkat kualitas kredit adalah gambaran kesehatan kredit yang telah diberikan oleh bank. Tingkat kualitas kredit tersebut dikenal dengan istilah kolektibilitas kredit. Mengenai kolektibilitas kredit tersebut diatur dalam Peraturan Bank Indonesia no. 7/2/PBI/2005 tentang penilaian kualitas aktiva Bank Umum.

Menurut PBI no. 7/2/PBI/2005 pasal 12 ayat 3 dijelaskan bahwa kolektibilitas kredit dibagi menjadi ${ }^{5}$ :

1) Performance Loan, yang terdiri dari :

a. Kredit Lancar, yakni kredit yang memiliki kualitas sehat. Dimana debitur tidak memiliki tunggakan pokok dan/atau bunga, mutasi rekening yang aktif dan bagian dari kredit yang dijamin dengan agunan tunai.

b. Kredit Dalam Perhatian Khusus, yakni debitur memiliki tunggakan pokok dan/atau bunga namun belum melampaui 90 hari kalender.

2) Non Performance Loan, yang terdiri dari :

a. Kredit Kurang Lancar, yakni kredit yang memiliki tunggakan pokok dan/atau bunga lebih 90 hari kalender. Debitur cenderung mengalami indikasi masalah keuangan.

b. Kredit Diragukan, yakni kredit yang memiliki tunggakan pokok dan/atau bunga lebih dari 180 hari kalender. Pada kategori ini, debitur dinilai telah melakukan wanprestasi terhadap seluruh prosedur kredit yang telah disepakati bersama.

c. Kredit Macet, yakni kredit yang telah jatuh tempo dari jangka waktu yang seharusnya. Pada kategori ini, bank mengalami kerugian operasional disebabkan tidak kembalinya modal awal bank untuk pemberian kredit yang bersangkutan.

Terkait dengan kualitas kredit, petugas bank harus benar - benar menerapkan standar prosedur operasional dengan berdasarkan pada prinsip kepercayaan dan kehati - hatian (Prudential). Hal ini dikarenakan kredit adalah sumber pendapatan bank (bunga) tetapi juga memiliki potensi untuk menjadi sumber kerugian bank. Semakin banyak kredit yang tergolong Non Performance Loan (NPL) maka bank harus menyediakan Cadangan Kerugian Pengurangan Nilai (CKPN) yang pada kelanjutannya akan berdampak pada laba/rugi yang akan diperoleh bank.

\footnotetext{
${ }^{5}$ Peraturan Bank Indonesia, http://www.bi.go.id, di akses 23 September 2014
} 


\section{Tingkat Kesehatan Bank}

Secara sederhana bank yang sehat adalah bank yang mampu menjalankan seluruh fungsi - fungsi perbankan terutama fungsi intermediasi dimana bank mampu menghimpun dana masyarakat yang memiliki kelebihan kemudian menyalurkannya dalam bentuk kredit kepada masyarakat yang membutuhkan.

Menurut Peraturan Bank Indonesia no. 131/1/PBI/2011 tentang penilaian tingkat kesehatan Bank Umum pasal 1 ayat 4 dijelaskan bahwa yang dimaksud tingkat kesehatan bank adalah hasil penilaian kondisi bank yang dilakukan terhadap risiko dan kinerja bank ${ }^{6}$.

Sedangkan menurut peraturan Otoritas Jasa Keuangan (OJK) no. 8/POJK.03/2014 tentang penilaian tingkat kesehatan Bank Umum Syariah dan Unit Usaha Syariah Pasal 1 Ayat 6 diterangkan bahwa tingkat kesehatan bank adalah hasil penilaian kondisi bank yang dilakukan berdasarkan risiko termasuk risiko terkait penerapan prinsip syariah dan kinerja bank atau disebut Risk-based Bank Rating?.

Tingkat kesehatan bank dilihat dari Non Performance Loan (NPL) adalah rasio jumlah kredit yang memiliki kecenderungan berisiko gagal bayar atau terindikasi mengalami masalah keuangan. NPL diukur dari perbandingan jumlah kredit yang bermasalah dengan jumlah kredit yang telah disalurkan.

Berdasarkan hal tersebut diketahui bahwa semakin tinggi nilai rasio NPL maka akan semakin rendah tingkat kesehatan bank atau NPL berbanding terbalik dengan tingkat kesehatan bank. Semakin banyak kredit yang tergolong Non Performance Loan (NPL) maka bank harus menyediakan Cadangan Kerugian Pengurangan Nilai (CKPN) yang pada kelanjutannya akan berdampak pada laba/rugi yang akan diperoleh bank.

Menurut Peraturan Bank Indonesia nomor 6/10/PBI/2004 tanggal 12 April 2004 tentang sistem penilaian tingkat kesehatan bank umum dinyatakan bahwa Bank Indonesia menetapkan Bank dalam pengawasan intensif jika dinilai memiliki potensi kesulitan yang membahayakan kelangsungan usahanya. Salah satu kriteria penilaian tersebut adalah jika rasio kredit bermasalah (Non Performance Loan) secara netto lebih dari 5\% (lima persen) dari total kredit. Sehingga nilai rasio yang ideal untuk NPL adalah dibawah $5 \%$ dan jika berada diatas $5 \%$ maka Bank Indonesia berhak melakukan pengawasan intensif. Pengawasan tersebut akan berdampak pada penilaian tingkat kesehatan bank. ${ }^{8}$

Disisi lain, Selain NPL, salah satu ukuran untuk menilai likuiditas bank adalah Loan to Deposits Ratio (LDR), yakni rasio antara seluruh jumlah kredit yang diberikan oleh bank dengan dana yang dimiliki oleh bank. LDR tersebut menggambarkan kemampuan bank dalam mengembalikan dana yang telah dialokasikan untuk kredit. Dengan Loan to Deposits Ratio (LDR) kita dapat mengetahui sejauh mana bank mampu mengoptimalkan potensi dana pihak ketiga yang telah dihimpun untuk kemudian disalurkan dalam bentuk kredit.

Jika nilai LDR rendah maka hal tersebut berarti bahwa bank kurang mampu mengoptimalkan penyaluran kredit dan akan menyebabkan bank

\footnotetext{
${ }^{6}$ Peraturan Bank Indonesia, http://www.bi.go.id, diakses 23 September 2014

${ }^{7}$ Peraturan Bank Indonesia, http://www.bi.go.id, diakses 23 September 2014

${ }^{8}$ Peraturan Bank Indonesia, http://www.bi.go.id, diakses 23 September 2014
} 
terbebani oleh bunga simpanan yang harus dibayarkan kepada nasabah. Namun, jika nilai LDR terlalu tinggi maka hal tersebut berarti bahwa bank kurang mampu melakukan penghimpunan dana pihak ketiga dan terlalu berlebihan dalam penyaluran kredit atau over loan. Hal ini dapat menyebabkan meningkatnya risiko kredit dan pada akhirnya akan berdampak terhadap tingkat kesehatan bank.

\section{Hubungan NPL dan LDR Terhadap Tingkat Kesehatan Bank}

Pengalokasian dana yang dimiliki oleh bank terbesar adalah dalam bentuk penyaluran kredit. Dimana kredit memberikan peluang keuntungan yang signifikan. Dari penyaluran kredit tersebut bank mampu membayar bunga simpanan, mengcover biaya operasional usahanya dan menyisihkan sebagian lainnya untuk dijadikan modal dalam bentuk laba ditahan.

Kegiatan usaha perbankan yang komplek menuntut bank untuk mengoptimalkan seluruh potensi sumber daya ekonomi yang tersedia. Salah satu caranya adalah menjaga kualitas kredit. Untuk mendapatkan keuntungan yang maksimal dari penyaluran kredit, bank harus mampu mengukur risiko kegagalan pengembalian kredit oleh debitur. Risiko kegagalan pengembalian kredit diistilahkan dengan Non Performance Loan (NPL). Semakin tinggi NPL maka semakin tinggi pula risiko kegagalan pengembalian kredit oleh debitur.

Bukan hanya risiko kegagalan bayar yang akan dihadapi jika tingkat NPL tinggi, biaya operasional pun ikut mengalami kenaikan. Dengan kata lain semakin tinggi NPL suatu bank maka kinerja bank akan mengalami penurunan.

Selain NPL, salah satu ukuran untuk menilai likuiditas bank adalah Loan to Deposits Ratio (LDR), yakni rasio antara seluruh jumlah kredit yang diberikan oleh bank dengan dana yang dimiliki oleh bank. LDR tersebut menggambarkan kemampuan bank dalam mengembalikan dana yang telah dialokasikan untuk kredit.

Menurut Peraturan Bank Indonesia no. 15/15/PBI/2013 pasal 1 ayat 8 dijelaskan bahwa LDR adalah rasio kredit yang diberikan kepada pihak ketiga dalam rupiah dan valuta asing, tidak termasuk kredit kepada bank lain, terhadap dana pihak ketiga yang mencakup giro, tabungan dan deposito dalam rupiah dan valuta asing, tidak termasuk dana antar bank ${ }^{9}$.

Pada Peraturan Bank Indonesia no. 15/15/PBI/2013 pasal 11 ayat 1 disebutkan bahwa batas bawah LDR Target adalah sebesar $78 \%$ dan batas atas LDR Target adalah 92\%. LDR Target adalah kisaran LDR yang digunakan untuk menentukan Giro Wajib Minimum (GWM). Sedangkan GWM adalah jumlah dana minimum yang wajib dipelihara oleh bank yang besarannya ditetapkan oleh Bank Indonesia sebesar persentase tertentu dari Dana Pihak Ketiga (DPK) ${ }^{10}$.

Setiap bank wajib menjaga kualitas LDR agar tetap berada pada range yang telah ditentukan. Apabila LDR Target berada dibawah batas minimum maka bank dapat dinilai tidak dapat mengoptimalkan potensi dana yang dimilikinya. Begitu pula jika LDR Target berada diatas batas maksimum maka bank dapat dinilai over loan, dimana penyaluran kredit melebihi dari ketersediaan dana yang dimiliki.

\footnotetext{
${ }^{9}$ Peraturan Bank Indonesia, http://www.bi.go.id, diakses 23 September 2014

${ }^{10}$ Peraturan Bank Indonesia, http://www.bi.go.id, diakses 23 September 2014
} 


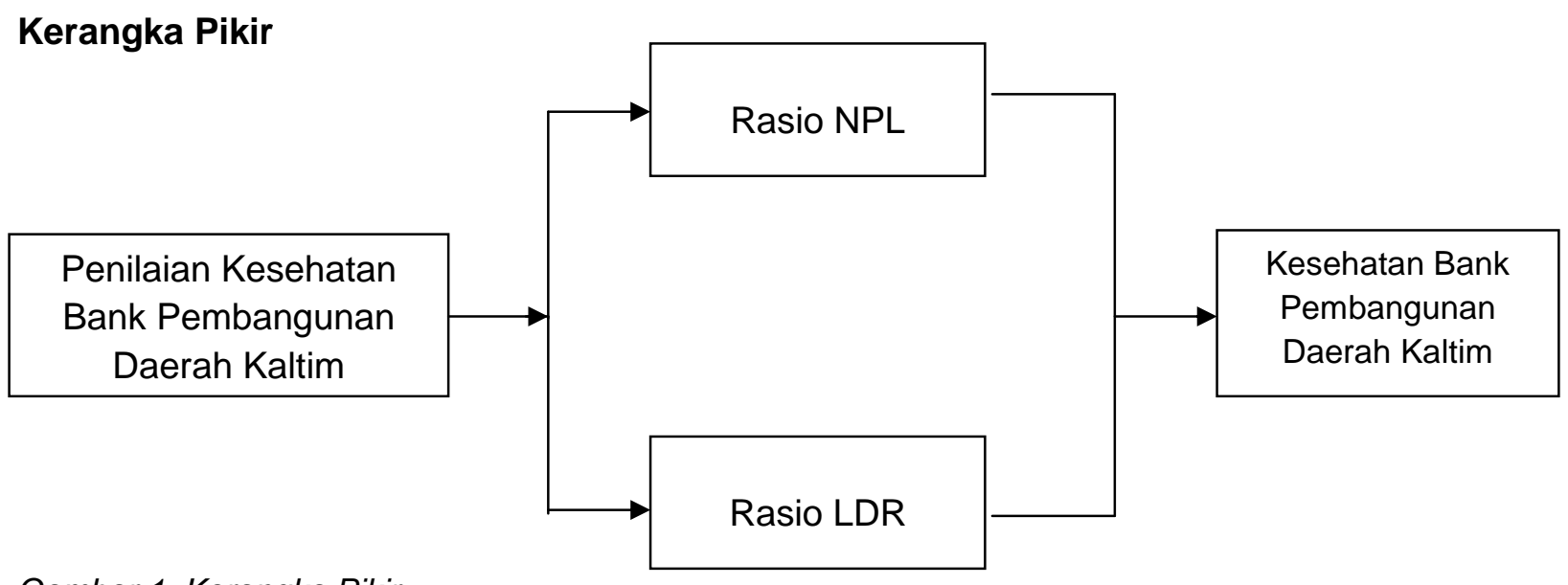

Gambar 1. Kerangka Pikir

\section{METODOLOGI PENELITIAN}

\section{Metode Penelitian}

Penelitian dilakukan dengan metode deskriptif kuantitaif yaitu penelitian penjelasan (explanatory Research) yang dilakukan untuk memperoleh gambaran yang sebenarnya tentang tingkat kesehatan pada Bank Pembangunan Daerah Kalimantan Timur. Dimana penelitiaan ini fokus terhadap variabel yang mempengaruhi tingkat kesehatan bank.

\section{Definisi Opersional Variabel dan Pengukuran}

Dalam penelitian ini terdapat variabel yang akan dipaparkan dalam upaya mengetahui tingkat kesehatan bank. Variabel tersebut adalah :

a. Laporan Keuangan

Laporan keuangan adalah laporan yang menyajikan kondisi keuangan sebuah perusahaan pada saat tertentu meliputi neraca, laporan laba rugi, laporan perubahan posisi keuangan dan beberapa hal yang terkait dengan struktur kinerja keuangan perusahaan. Dalam penelitian ini laporan keuangan yang akan diukur adalah periode 2009 - 2013.

b. NPL

Non Performance Loan adalah jumlah kredit yang memiliki kecenderungan berisiko gagal bayar atau terindikasi mengalami masalah keuangan. NPL diukur dari perbandingan jumlah kredit yang bermasalah dengan jumlah kredit yang telah disalurkan. Laporan NPL diperoleh melalui Master Loan Filter yang terbit setiap akhir bulan namun untuk menjaga kualitas kredit harus dipantau setiap harinya melalui laporan keuangan harian. Pada penelitian ini, NPL yang akan diukur adalah laporan NPL yang termuat dalam laporan kinerja keuangan dalam laporan tahunan atau annual report periode $2009-2013$.

c. $L D R$

Loan to Deposits Ratio adalah rasio kredit yang diberikan kepada pihak ketiga dalam rupiah dan valuta asing, tidak termasuk kredit kepada bank 
lain, terhadap dana pihak ketiga yang mencakup giro, tabungan dan deposito dalam rupiah dan valuta asing, tidak termasuk dana antar bank. Laporan LDR adalah laporan olahan yang diperoleh dari laporan likuiditas bank. Pada penelitian ini, laporan likuiditas tersajikan dari neraca per 31 Desember yang telah diaudit oleh pihak eksternal/independen periode 2009 2013.

\section{Tehnik Pengumpulan Data}

Untuk mengumpulkan data penulis menggunakan teknik Pengumpulan sebagai berikut :

1. Teknik Dokumentasi, yaitu melakukan pengumpulan dokumen resmi yang dikeluarkan atau diterbitkan oleh perusahaan yang berupa sumber tertulis, lisan, gambar dan karya - karya yang memberikan informasi bagi proses penelitian,

2. Teknik wawancara, yaitu dengan melakukan tanya jawab secara langsung dengan pihak - pihak yang terkait dalam penyediaan informasi/ data yang diperlukan dalam penelitian,

3. Teknik Kepustakaan, yaitu dilakukan dengan cara mengumpulkan dan mempelajari teori-teori dan literatur yang berhubungan dengan judul penelitian.

\section{Metode Analisis}

1. Non Performan Loan (NPL) yakni rasio penilaian kualitas aset yang menunjukkan kemampuan manajemen bank dalam mengelola kredit bermasalah yang telah diberikan oleh pihak bank. Semakin tinggi NPL akan berpengaruh pada biaya operasional dan pada akhirnya akan mengganggu kinerja keuangan bank. NPL dapat dirumuskan dengan :

$\mathrm{NPL}=\frac{\text { Seluruh Baki Debet Kredit Bermasalah }}{\star}{ }_{\text {Seluruh Baki Debet Kredit }} 100 \%$

Penilaian kinerja keuangan Non Performing Loan (NPL)

\begin{tabular}{|c|c|}
\hline Tingkat & Predikat \\
\hline Diatas 5\% & Kurang Sehat \\
\hline Dibawah 5\% & Sehat \\
\hline
\end{tabular}

Sumber: www.bi.go.id 
2. Loan to Deposits Ratio (LDR) yakni rasio likuiditas bank yang menunjukkan kemampuan bank dalam membayar kembali kewajiban kepada nasabah yang telah menanamkan dananya dengan kredit yang telah diberikan oleh bank. LDR dapat dirumuskan dengan :

LDR $=\frac{\text { seluruh baki debet } \text { kredit }_{*}}{\text { selruh dana pikak ketiga }}+100 \%$

Penilaian Kinerja Keuangan LDR :

\begin{tabular}{|c|c|}
\hline Tingkat & Predikat \\
\hline Diatas $105 \%$ & Tidak Sehat \\
\hline $92 \%-105 \%$ & Kurang Sehat \\
\hline $78 \%-92 \%$ & Sehat \\
\hline Dibawah $78 \%$ & Tidak Sehat \\
\hline
\end{tabular}

Sumber: www.bi.go.id

\section{ANALISIS DAN PEMBAHASAN}

\section{Analisis Data}

Berdasarkan data yang disajikan dan hasil penelitian yang dikemukakan penulis pada bab - bab sebelumnya, maka dalam analisis ini akan dibahas mengenai rasio - rasio keuangan dan standar kesehatan bank yang berkaitan dengan kinerja keuangan perbankan, dengan analisis tersebut diharapkan kita dapat mengetahui mengapa kinerja keuangan bank tersebut menurut dan menjadi bank yang bermasalah atau sebaliknya. Untuk lebih lanjut akan dijelaskan disini mengenai permasalahan diatas, adapun kineja keuangan perbankan dapat dilihat pada penjelasan dibawah ini :

1. Non Performance Loan (NPL)

\begin{tabular}{|c|c|c|c|c|c|c|}
\hline \multirow{2}{*}{ NO } & \multicolumn{5}{|c|}{ TAHUN *(neraca dalam Jutaan Rupiah) } \\
\cline { 3 - 7 } & 2009 & 2010 & 2011 & 2012 & 2013 \\
\hline \multirow{2}{*}{ RASIO NPL } & $\mathbf{0 , 4 5 \%}$ & $\mathbf{1 , 9 2 \%}$ & $\mathbf{1 , 3 4 \%}$ & $\mathbf{4 , 3 0 \%}$ & $\mathbf{2 , 2 3} \%$ \\
\hline
\end{tabular}

Sumber : data diolah 
2. Loan to Deposits Ratio (LDR)

$$
\operatorname{LDR}=\frac{\text { Total Kredit }}{\text { Giro }+ \text { Tabungan }+ \text { simpana Berjangka }+ \text { Modal }} \times 100 \%
$$

\begin{tabular}{|c|c|c|c|c|c|c|}
\hline \multirow{2}{*}{ NO } & \multirow{2}{*}{ RASIO KEUANGAN } & \multicolumn{5}{|c|}{ TAHUN *(neraca dalam Jutaan Rupiah } \\
\cline { 3 - 7 } & & 2009 & 2010 & 2011 & 2012 & 2013 \\
\hline 1 & TOTAL KREDIT & 7.311 .523 & 9.508 .892 & 11.214 .895 & 14.458 .696 & 18.588 .373 \\
\hline 2 & DANA PIHAK KETIGA & 10.534 .916 & 11.608 .253 & 19.254 .036 & 26.143 .623 & 21.048 .777 \\
\hline \multicolumn{2}{c|}{ RASIO LDR } & $\mathbf{6 9 , 4 0 \%}$ & $\mathbf{8 1 , 9 1 \%}$ & $\mathbf{5 8 , 2 5 \%}$ & $\mathbf{5 5 , 3 0 \%}$ & $\mathbf{8 8 , 3 1 \%}$ \\
\hline
\end{tabular}

Sumber : data diolah

\section{Pembahasan}

Kesehatan bank dapat diartikan sebagai kemampuan bank untuk melakukan kegiatan operasional perbankan secara normal dan mampu memenuhi semua kewajibannya dengan baik dengan cara-cara yang sesuai dengan peraturan perbankan yang berlaku. Agar suatu bank dapat menjalankan seluruh kegiatannya dengan baik, maka tindakan yang perlu dilakukan adalah perencanaan, pengoperasian, pengendalian, dan pengawasan. Proses aliran keuangan secara terus menerus dan mencatatnya dalam laporan keuangan yang terdiri dari neraca dan perhitungan rugi - laba.

Berdasarkan hasil perhitungan rasio NPL selama lima tahun pada tahun 2009 sampai dengan 2013 BPD Kaltim memperoleh kenaikan/penurunan persentase NPL yaitu sebesar 1,47 point di tahun 2009-2010 dengan nilai persentase $0,45 \%$ di tahun 2009 menjadi 1,92\% tahun 2010 hal ini disebabkan meningkatnya penyaluran kredit yang tidak diiringi dengan pemeliharaan kualitas kredit, dimana kredit yang telah tersalurkan menunjukkan gejala kecenderungan menurun kualitas dan masuk ke Non Performance Loan, kemudian tahun 2011 persentase NPL mengalami penurunan menjadi 1,34\%, pada tahun 2012 mengalami peningkatan NPL menjadi $4,3 \%$ hal ini disebabkan adanya penyaluran kredit yang cenderung stagnan dan situasi ekonomi yang masih dalam masa pemulihan dari imbas krisis ekonomi global dan pada tahun 2013 mengalami penurunan kembali menjadi $2,23 \%$. Walaupun setiap tahun mengalami fluktuasi, tetapi nilai persentase yang diperoleh Bank Kaltim masih dalam kategori Sehat.

Hasil Perhitungan rasio Loan to Deposit Ratio (LDR) selama lima tahun yaitu pada tahun 2009 sampai dengan 2013 Bank Pembanguan Daerah Kalimantan Timur memperoleh rasio fluktuatif mengikuti trend penyaluran kredit dan manajemennya. Ada 3 periode dimana Bank Pembangunan Daerah Kalimantan Timur tercatat memiliki rasio LDR dibawah $70 \%$ yakni pada tahun 2009 sebesar 69,40\%, pada tahun 2011 sebesar 58,25\% dan pada tahun 2012 sebesar $55,30 \%$. Hal ini dapat diartikan bahwa pada periode tersebut BPD Kaltim 
tidak mampu memaksimalkan dana yang dihimpunya dengan melakukann penyaluran kredit.

Dengan demikian pada periode tersebut BPD Kaltim masuk kategori Kurang Sehat. Penurunan tingkat kesehatan sebuah perusahaan merupakan risiko yang pasti dihadapi oleh setiap perusahaan dunia usaha. Adanya faktor eksternal seperti belanja pemerintah dengan anggaran yang besar, bencana alam, meningkatnya pengeluaran masyarakat disebabkan krisis ekonomi yang memicu inflasi dan kondusifitas lingkungan sosial politik juga dapat mempengaruhi tingkat kesehatan bank. Dimana faktor eksternal tersebut mengakibatkan turunnya antusias masyarakat untuk menggunakan produk jasa perbankan, berkurangnya dana taktis untuk menjalankan aktivitas perbankan dan berkurangnya minat investor. Namun, pada periode lainnya dengan memaksimalkan potensi perusahaan dan meminimalisir risiko BPD Kaltim mampu meningkatkan kualitas LDR-nya. Terlihat pada periode 2010 nilai LDR berada pada posisi $81,91 \%$ dan $88,31 \%$ pada tahun 2013. Dengan demikian BPD Kaltim dapat dikategorikan bank sehat.

\section{KESIMPULAN DAN SARAN}

\section{Kesimpulan}

Kesimpulan adalah jawaban dari perumusan masalah yang menjadi dasar penelitian ini. Berdasarkan hasil analisis dan pembahasan terhadapa analisis kinerja keuangan pada Bank Pembangunan Daerah Kalimantan Timur periode tahun 2009 sampai dengan 2013, dapat ditarik kesimpulan sebagai berikut :

1. Nilai Non Performance Loan (NPL) adalah jumlah kredit yang memiliki kecenderungan gagal bayar atau terindikasi mengalami masalah keuangan sehingga menimbulkan wanprestasi terhadap kontrak yang telah disepakati. BPD Kaltim pada periode 2009 - 2013 memiliki NPL yang fluktuatif, tetapi secara umum rasio NPL adalah rata - rata 2,05\%. Dari nilai tersebut BPD Kaltim dikategorikan dalam kelompok bank sehat. Hal ini menunjukkan bahwa BPD Kaltim mampu mengelola seluruh potensi kredit yang telah disalurkan.

2. Rasio LDR (Loan to Deposit Ratio) adalah untuk menilai likuiditas suatu bank yang dengan cara membagi jumlah kredit yang diberikan oleh bank terhadap dana ketiga. BPD Kaltim pada tahun 2009 - 2013 memiliki rasio yang fluktuatif setiap tahunnya dengan rata - rata $70,63 \%$. Kurang optimalnya penyaluran kredit dan sebagai Bank milik pemerintah daerah maka BPD Kaltim sangat bergantung pada dana pemerintah yang ditempatkan. Dari rasio yang diperoleh secara umum BPD Kaltim masuk kategori bank sehat.

\section{SARAN}

Dari hasil kesimpulan yang dikemukakan pada penelitian ini, ijinkan kami menyampaikan saran-saran yang masih berpegang pada pendapat para pakar perbankan dalam beberapa buku yang terjadi landasan teori pada pembahasan laporan ini.

Adapun saran-saran tersebut adalah sebagai berikut: 
1. Untuk manajemen BPD Kaltim terkait dengan NPL kiranya dapat mempertahankan kualitas kredit dengan melakukan pengawasan kredit yang memiliki potensi menurun dari kolektibilitas 2 ke kolektibilitas 3 dan/atau selanjutnya.

2. Berdasarkan hasil penelitian yang telah dipaparkan diketahui bahwa tingkat Loan to Deposits Ratio (LDR) BPD Kaltim mengalami fluktuasi pada tiap tahunnya, sehingga disarankan untuk meningkatkan penghimpunan terhadap dana pihak ketiga yang murni swasta atau non pemerintah.

\section{DAFTAR PUSTAKA}

Ikatan Akuntan Indonesia, 2002. Standar Akuntansi Keuangan, Penerbit Salemba Empat, Jakarta.

Intan, Ayu Putri, dkk, Rasio CAMEL sebagai Indikator Tingkat Kesehatan dan kebangkrutan perbankan, skripsi (S1), 2010 http://www.perpustakaan.uns.ac.id, diakses 23 September 2014.

Kasmir, 2002. Dasar-dasar Perbankan, Edisi Pertama, Cetakan Pertama, Penerbit-PT. Raja Grafindo Persada, Jakarta.

2000. Manajemen Perbankan, Edisi Pertama, Cetakan Pertama, Penerbit-PT.Raja Grafindo Persada, Jakarta.

Peraturan Bank Indonesia, http://www.bi.go.id, diakses 23 September 2014

Peraturan Otoritas Jasa Keuangan, http://www.ojk.go.id, diakses 23 September 2014.

Saragih, Yunita, Analisis Pengaruh Non Performance Loan (NPL) dan Loan to Deposits Ratio (LDR) terhadap Profitabilitas PT. Bank Tabungan Negara Persero), Skripsi (S1), 2011 http://elib.unikom.ac.id, diakses 23 September 2014.

Undang - Undang Republik Indonesia no. 13 tahun 1968 tentang Bank Sentral, http://www.ojk.go.id, diakses 23 September 2014, halaman 7.

Undang - Undang Republik Indonesia no. 7 tahun 1992 tentang Perbankan, http://www.ojk.go.id, diakses 23 September 2014, halaman 4. 
71 Jurnal Ekonomika Fekon UWGM 